\title{
Research on the Influencing Factors of High School English Teacher Professional Learning Community Evaluation in Changchun, China
}

\author{
Yang $\mathrm{Li}^{1} \&$ Chia-Ching $\mathrm{Tu}^{1}$ \\ ${ }^{1}$ Department of Educational Management, CHINA-ASEAN International College, Dhurakij Pundit University, \\ Thailand \\ Correspondence: Chia-Ching Tu, Department of Educational Management, CHINA-ASEAN International \\ College, Dhurakij Pundit University, Thailand. Tel: 66-967-937-339. E-mail: chia-ching.tu@dpu.ac.th; \\ liou0929@yahoo.com.tw
}

Received: March 4, 2018 Accepted: April 19, 2018 Online Published: April 21, 2018

doi: 10.5539/elt.v11n5p104 URL: http://doi.org/10.5539/elt.v11n5p104

\begin{abstract}
This research shows the development and influencing factors of high school English teachers' evaluation of professional learning community in Changchun, China. Followed Olivier and Hipp \& Huffma's research, the teacher professional learning community evaluation questionnaire was developed by the researchers. 422 English teachers in Changchun were invited to participate in the online survey. This study found that the organization characteristics of professional learning communities in this city shared similar characteristics with Western countries at some degree. English perceptions of including the "shared personal practice" and "collective learning and application" achieves the average level in this research. Compared to the western professional learning communities, the Chinese professional learning communities in this study lack of the democratic leadership and shared value and vision attributions. According to the analysis, we find that the Confucian cultural context, teacher' career development stages, the pressures of national college entrance examination and the systematic teaching training have a significant impact on the evaluation of teacher professional learning communities. Aiming at to build a learning organisation rather than a bureaucratic administration, we suggest that the "shared value and vison" and "shared and supportive leadership" needs more reform in the current professional learning communities. Namely, traditional Soviet model of school-based professional learning communities need to reform toward a learning organisation emphasizing the teaching and learning.
\end{abstract}

Keywords: teacher professional learning community, Chinese cultural context, Changchun, shared personal practice

\section{Introduction}

In this information era, along with the trend of knowledge economy and lifelong learning, aiming at to promote students' learning with quality teaching, all countries have begun to reform the schools by building the learning communities since the beginning of the 1980s. Scholars represented by Hord, DuFour and so on find that teachers in school as an important part have a positive effect on the school-based curriculum development, teacher cooperation, school improvement, and student learning (DuFour \& Eaker, 2005; Hord, 1998). Since then, the relative research of professional learning community in schools has become a hot topic in the field of education. The three words -- "professional", "learning" and "community" -- explain its organizational characteristics in a concise way. Professional learning community can be defined as teachers in school form a cooperative group for the purpose of professional learning. It emphasizes the collaboration learning and professional growth of teachers in the workplace (Hipp \& Huffman, 2003). Currently, the construction of teacher professional learning communities has become one of the goals for all schools. However, how to build effective professional learning communities and maintain their sustained effects on teachers' development remains a puzzle and needs further research. Most of the studies explore the development and improvement of teacher professional learning community in Europe and the United States. While the surveys on Asian schools with Confucian culture and hierarchical system is less (Hairon \& Dimmock, 2012; Zhang \& Pang, 2016; Zhang \& Sun-Keung Pang, 2016). Since 1950s, the Chinese government has required all primary and secondary schools to organise the teaching unit like teaching and research group. This kind of organisation is similar to the western teacher professional learning in terms of organization form, activity content and activity goal (Shan, 2014). 
Against this backgrounds, we developed this research to explore professional learning communities' influencing factors in the hierarchical management system.

\section{Literature Reviews}

During these 30 years, scholars have studied the constitute elements, construction steps of effective and sustain professional learning community. Factors containing shared values and vision, supportive and shared leadership, collective learning and application, supportive conditions, reflective professional enquiry, mutual trust, respect and support and shared personal practice have been identified as key components of effective professional learning community (Bolam et al., 2005; DuFour \& Eaker, 2005; Hord, 2004). Teacher professional learning community has been evidenced to have positive effects on educational reform, student achievement, teacher attitude change, teaching practice, teacher commitment on students and teacher professional development (I. Lee, 2015; J. C.-K. Lee, Zhang, \& Yin, 2011; Stoll, Bolam, McMahon, Wallace, \& Thomas, 2006; Vescio, Ross, \& Adams, 2008).

In recent years, more studies have been done on the influence factors which contribute to the development of professional learning communities. Gray, Keuse and Tarter's data contends that "enabling school structures, collegial trust and academic emphasis are antecedents to the development of professional learning communities (Gray, Kruse, \& Tarter, 2016).” In addition, school leaders' attendance in formal organizations and activities have a positive effect on building collegial trust. De Neve and Devos' research supports these findings. Their study revealed that school leaders play an important role in supporting the collaboration between teachers and guiding the development of professional learning communities (De Neve \& Devos, 2017). In this research, they identified that reflective dialogue is a typical symbol of mature a professional learning communities and the principle leadership is a crucial element of promoting teachers' participation in the reflective dialogue.

In the current Chinese school system, we identified three categories professional learning communities that shoulder the responsibilities to promote in-service teacher's professional development and professional learning.

The first category is the traditional school-based organizations. Such as the Teaching and Research Group. In 1957, guided by the Soviet Union's "teaching method group", the Ministry of Education promulgated the Ordinance (Draft) of Middle School Teaching Research Group. It required all primary and secondary schools to establish teaching and research orginisation. The Teaching and Research Group was gradually established according to different subjects. Lately, similar groups like the Lesson Preparation Teams and Grade Group were successively carried out (Shan, 2014).

The second is the new types professional learning community, such as Master Studio, Regional Professional Learning Community. The Master Studio is one of the patterns of localized exploration of professional learning. It is supervised by one or more teachers who win the title of National Supreme Teacher. This group integrates traditionally mentoring system, conforms the social characteristics of knowledge and learning (Han \& Yu, 2014). Regional Professional Learning Community is a learning organization based on the division of administrative units. It balances the distribution of schools and teachers' resources in the region and combines teachers' daily professional practices with their professional development. The regional learning community integrates the resources of schools and collects all the teachers in a certain administrative area.

The third is the network virtual learning community. This kind of community is a new way of professional learning after the popularization of Internet technology and computer, mobile phone and other technical terminals, such as QQ group, Wechat group, blog, Open University Class and national remote continuing education website and so on.

The Outline of the National Medium \& Long-Term Education Reform and Development Plan (2010-2020) in China points out that "Teachers are the key to the success of education project. Without good teachers, we cannot achieve the quality education. Therefore, we should strictly enforce the qualification of teachers, improve the quality of teachers, and aspire to create a high-quality professional teacher team with noble ethics, exquisite professionalism, reasonable structure and full vitality." In recent years, in order to cultivate high quality teachers, Chinese schools have make an effort to promote the in-service teachers' professional development.

At present, a number of discussions have been launched in the schools with frontier education practices, teachers and educational scholars in view of existing problems of professional learning community in practices and theories. After searching in the China's largest academic journal network - CNKI - with the key word "Teacher Professional Learning Community", there are around 1300 records of journals and theses focusing on the "teacher professional learning community". In the current study, it is mainly concentrated in the following five aspects: the introduction to the development and evolution of international teachers' professional learning 
community, the construction strategy of teacher professional learning community in different regions or subjects, the relationship between the teacher professional development and self-efficacy of professional learning community, the analysis of the existing problems and the improvement strategy of traditional teaching and research group, and the promotion of virtual professional learning community. However, there are few researches explore the evaluation of the professional learning community from the teachers' perspective. Hence, this research was developed to solve the following three questions:

How is the development of high school English teacher professional learning community in Changchun, China?

What are the differences in the evaluation of the professional learning community from the high school English teachers in different school environments?

What are the differences in the evaluation of professional learning community from high school English teachers in different teacher backgrounds?

\section{Methodology}

The main purpose of this study is to investigate the evaluation of Chinese high school English teachers on professional learning communities and their influencing factors. In order to achieve this goal, the researchers investigated senior English teachers in Changchun by using the questionnaire of Chinese high school English teachers' professional learning community evaluation. The SPSS24.0 was used to analyze the dataset.

\subsection{Instrument}

This study followed Oliver et al. research of professional learning community assessment. Their questionnaire "Professional Learning Community Assessment-Revised (PLCA-R)" (Olivier, Hipp, \& Huffman, 2010) served as an effective formal diagnostic tool for identifying school-level practices that enhance intentional professional learning. The original questionnaire is divided into five dimension "shared and supportive leadership" (11 items), "shared values and vision" (9 items), "collective learning and application" (10 items), "shared personal practice" (7 items) and "supportive conditions" (9 items).

Firstly, researchers literally translated all the items of the PLCA-R. Then, combined with eight single choice question demographic information, two single-choice question of school information, and two multi-choices question of the type and participation of professional learning communities, we developed the pre-questionnaire of PLCA-R in Chinese. The questions for the professional learning communities were divided into three types. There are 1. traditional professional learning community, teaching and research group, lesson preparation group and grade group; 2.new professional learning community, Master studio, regional professional learning community, 3. online professional learning communities, QQ group and Wechat group.

Secondly, a focus group, including the professors from teacher education and English teachers from high schools, was held to discuss the items of the pre-questionnaire. Considering the Chinese high school context, 7 items which cannot be applied to China, such as the stakeholders from the government, were deleted.

Thirdly, a pre-text containing 47 items was conducted to examine the validity and internal consistency reliability of the questionnaire. In total, 111 effective questionnaires were analyzed by the SPSS. 5 items were deleted because of the lower explanation. Because there were only two items that were evidenced to include in the "supportive conditions", this dimension was deleted at the end. In sum, 10 items were deleted from the pre-text. The rest 25 items of extraction of eigenvalues greater than 1 . It can contribute to the $77.7 \%$ to the English teachers' evaluation of the professional learning communities. The Cronbach Alpha reliability coefficients for four dimensions were "Shared and Supportive Leadership" (.94), "Shared Values and Vision" (.85), "Collective Learning and Application" (.94), "Shared Personal Practice (.91)".

Finally, the formal questionnaire was developed including 25 Five-Likert items from PLCA-R and 12 items of background information.

\subsection{The Survey}

After the formal questionnaire was designed, this survey was conducted via the network platform: wjx.cn. In total, 484 high school English teachers from 42 high schools in Changchun participated in this survey. After excluding 62 invalid questionnaires whose answers are too short or options are almost exactly the same, 422 valid questionnaires were collected. The percentage of valid questionnaire reaches $87.2 \%$.

The demographic information of the sample is presented in Table 1. Samples are mainly female teachers (346) with more than 10 years' teaching experiences (317). Among them, 341 teachers are between 31-50 years old. $22.7 \%$ of the teachers have a master's degree, and $76.3 \%$ of them has a bachelor degree, of which about $80 \%$ graduating from the English Major in the teacher training Universities. Only 87 teachers do not obtain the 
professional English certification. 76 teachers are the leader of the English teacher professional learning community. $51.4 \%$ of teachers come from ordinary schools and 230 teachers belong to large-scale schools with more than 36 teaching classes.

Table 1. Summary of the demographic information

\begin{tabular}{|c|c|c|c|}
\hline Dimension & Type & Frequency & Percent $(\%)$ \\
\hline \multirow[t]{2}{*}{ Gender } & Female & 346 & 82.0 \\
\hline & Male & 76 & 18.0 \\
\hline \multirow[t]{5}{*}{ Age } & $21-25$ & 10 & 2.4 \\
\hline & $26-30$ & 52 & 12.3 \\
\hline & $31-40$ & 221 & 52.4 \\
\hline & $41-50$ & 120 & 28.4 \\
\hline & $51-60$ & 19 & 4.5 \\
\hline \multirow[t]{4}{*}{ Teaching experiences } & $1-5$ & 52 & 12.3 \\
\hline & $6-10$ & 53 & 12.6 \\
\hline & $10-15$ & 125 & 29.6 \\
\hline & Over 15 & 192 & 45.5 \\
\hline \multirow[t]{3}{*}{ Education level } & Master & 96 & 22.7 \\
\hline & Bachelor & 322 & 76.3 \\
\hline & Junior college & 4 & 0.9 \\
\hline \multirow[t]{2}{*}{ The type of graduated university } & $\begin{array}{l}\text { Teacher } \\
\text { University }\end{array}$ & 368 & 87.2 \\
\hline & Comprehensive university & 54 & 12.8 \\
\hline \multirow[t]{3}{*}{ Major } & English Major & 372 & 88.2 \\
\hline & Education Major & 40 & 9.5 \\
\hline & Other Majors & 10 & 2.4 \\
\hline \multirow[t]{3}{*}{ English certification } & Tem 8 & 176 & 41.7 \\
\hline & Tem 4 & 159 & 37.7 \\
\hline & No & 87 & 20.6 \\
\hline \multirow{2}{*}{$\begin{array}{l}\text { Whether the leader of the } \\
\text { professional learning community } \\
\text { or not }\end{array}$} & Yes & 76 & 18.0 \\
\hline & No & 346 & 82.0 \\
\hline \multirow[t]{3}{*}{ School Level } & High reputation & 123 & 29.1 \\
\hline & Average school & 82 & 19.4 \\
\hline & Ordinary School & 217 & 51.4 \\
\hline \multirow[t]{3}{*}{ School Size } & $\begin{array}{l}\text { Large (more than } 36 \\
\text { teaching classes) }\end{array}$ & 230 & 54.5 \\
\hline & $\begin{array}{l}\text { Medium (18-36 teaching } \\
\text { classes) }\end{array}$ & 159 & 37.7 \\
\hline & $\begin{array}{l}\text { Small (less than } 18 \\
\text { teaching classes) }\end{array}$ & 33 & 7.8 \\
\hline
\end{tabular}

After that, we used SPSS 24.0 to analyse the questionnaire. Three methods including descriptive statistics analysis, T-test, one-way ANOVA were applied to analyse the influencing factors of teacher professional learning communities' evaluation. 


\section{Results}

\subsection{Summary of Effective Professional Learning Community in Changchun}

The results in the Table 2 present that Chinese professional learning communities in Changchun exhibit similar characteristics with western style. The average score of professional learning community's evaluation achieves 3.62. Four dimensions' evaluation witnesses a fluctuation differences between each other." Shared personal practice " ranks the highest score $\mathrm{M}=3.87$. Following by the "collective learning and application" $(\mathrm{M}=3.75)$, shared value and vision $(\mathrm{M}=3.67)$ stays in the third. Among them, the "shared and supportive leadership" $(\mathrm{M}=3.34)$ experiences the lowest score. Its score even remains lower than the average score.

Table 2. Summary of high school English teachers' professional learning community evaluation $(n=422)$

\begin{tabular}{lclllll}
\hline Dimensions & $\alpha$ & Maximum & Minimum & SD & Mean & Ranks \\
\hline Shared personal practice (5 items) & .93 & 5.00 & 1.00 & .81 & 3.87 & 1 \\
$\begin{array}{l}\text { Collective learning and Application } \\
\text { items) }\end{array}$ & $(9.93$ & 5.00 & 1.67 & .77 & 3.75 & 2 \\
Shared value and vision (3 items) & .88 & 5.00 & 1.17 & .87 & 3.47 & 3 \\
Shared and Supportive Leadership (8 items) & .94 & 5.00 & 1.00 & .98 & 3.34 & 4 \\
Overall & & 4.95 & 1.53 & .77 & 3.62 & \\
\hline
\end{tabular}

When we look the data in detail, some unique trends have been identified by the researchers. Firstly, because the "shared and supportive leadership" dimension was beyond the average level. We looked at the details of each items. The evaluation on the leadership and decision-making activities like "the leader of PLCs is proactive and addresses areas where support is needed $(\mathrm{M}=3.14)$, the leader of PLCs incorporates advice from teachers to make decisions $(\mathrm{M}=3.18)$, the leader of PLCs shared responsibility and rewards for innovative actions( $M=3.21$ )" are lower than an average of 3.63. Secondly, at the "shared value and vision" dimension level, the same case appears again. The English teachers marked a lower score to the item "a collaborative process exists for developing a shared sense of values among staff $(\mathrm{M}=3.73, \mathrm{SD}=1.084)$ ". In sum, sample teachers' perceptions of shared leadership and decision-making activities in the Chinese professional learning communities stay at a lower level on the one hand.

On the other hand, at the "shared personal practice" level, evaluation of "discuss strategies of promoting students' learning with colleagues in private" got a high score $(\mathrm{M}=4.02, \mathrm{SD}=.894)$ among all the items. Compared to the formal cooperation among staff, English teachers tend to discuss the questions in informal ways.

Among all the items, item "school goals focus on student learning beyond test scores and grades." keeps the lowest score ( $\mathrm{M}=2.72, \mathrm{SD}=1.206)$.

According to the descriptive statistics, the development and participation of professional learning communities are shown in Table 3. The Teaching and research group and the lesson preparation group are the most popular professional learning communities. The grade group, QQ group and Wechat group ranks second. As the two new professional learning communities, master studio (28.4\%) and regional professional learning community (13.7) need to be developed. In terms of participation, lessons preparation group has the highest score, which has reached $93.8 \%$ while the participation in the regional professional learning communities is relatively low, which is only $15.6 \%$. Generally, regional community is usually set up in one or a few schools in a certain school district and some professional development activities of discipline teachers are organized by these schools. As a result, the percentage of its participation is higher than the percentage of its existence. 
Table 3. Development of high school English teacher professional learning community and teachers' participation in different types

\begin{tabular}{lll}
\hline & Development & Participation \\
\hline Teaching and Research Group & $93.1 \%$ & $78.9 \%$ \\
Lesson Preparation Group & $96.9 \%$ & $93.8 \%$ \\
Grade Group & $69.2 \%$ & $65.9 \%$ \\
Master's Studio & $28.4 \%$ & $17.3 \%$ \\
Regional Professional Learning Community & $13.7 \%$ & $15.6 \%$ \\
QQ Group / Wechat Group & $77.3 \%$ & $73.5 \%$ \\
\hline
\end{tabular}

\subsection{Influencing FActors on the Evaluation of Professional Learning Community}

During the analysis process, $\mathrm{T}$ test was used to investigate the gender of teachers, whether they graduate from teaching training universities or whether they are the leader of professional learning communities. The results are demonstrated in Table 4. The results of ANOVA and LSD Post Examination on teacher's age, teaching experiences, academic degree, disciplines and majors, English certification, school level and size are shown in Table 5. The final outcomes of the four dimensions were synthesized in Table 6.

In accordance with Table 4 , both gender $(t=.540, p=.590)$ and leader identity $(t=.299, \mathrm{p}=.765)$ did not present any influences on the assessment of professional learning community. Whether or not to graduate from a teach training university has a significant impact on the evaluation of the teachers' effective professional learning community $(\mathrm{t}=-3.004, \mathrm{p}=.004)$. Teachers graduated from the teacher training colleges, on the contrary to the researchers' expectations, offer a lower estimation to the professional learning communities. Considering with the advanced pedagogical theories which had been provided to those teaching training universities, we suppose that the implementation of professional learning communities might below these English teachers' expectations. Also, it might be possible that there is a gap between the pedagogical theory and its implementation in Chinese schools.

Table 4 . T test summary of professional learning community evaluation

\begin{tabular}{|c|c|c|c|c|c|c|c|}
\hline Dimensions & Sex & $\mathrm{n}$ & $\mathrm{M}$ & $\mathrm{SD}$ & $\mathrm{t}$ & $\mathrm{p}$ & Difference \\
\hline \multirow{2}{*}{ Gender } & 1.female & 346 & 3.6319 & .78761 & \multirow[t]{2}{*}{.540} & \multirow[t]{2}{*}{.590} & \multirow[t]{2}{*}{ ns } \\
\hline & 2.male & 76 & 3.5789 & .70627 & & & \\
\hline \multirow{2}{*}{$\begin{array}{l}\text { Graduated } \\
\text { teacher } \\
\text { university }\end{array}$} & 1.yes & 368 & 3.5835 & .77908 & \multirow[t]{2}{*}{$-3.004 *$} & \multirow[t]{2}{*}{.004} & \multirow[t]{2}{*}{$2>1$} \\
\hline & 2.no & 54 & 3.8870 & .68000 & & & \\
\hline \multirow{2}{*}{$\begin{array}{l}\text { Leader of the } \\
\text { community }\end{array}$} & 1.yes & 76 & 3.6464 & .77057 & \multirow[t]{2}{*}{.299} & \multirow[t]{2}{*}{.765} & \multirow[t]{2}{*}{$\mathrm{ns}$} \\
\hline & 2.no & 346 & 3.6171 & .77462 & & & \\
\hline
\end{tabular}

Note: $* \mathrm{p}<.05$, ns means for no significant difference.

Table 5 presents the overall analysis of ANOVA.

First, teachers with different ages present significantly difference in overall evaluation for professional learning community. In general, young teachers under the 30 years old has higher evaluation than that teachers over 31 years old. Among them, teachers of 41-50 years old show the lowest evaluation on all dimensions than those of other ages. In the "leadership" level, as the age increases, teachers' evaluation is declining.

Second, with the increase of teachers' teaching experiences, the overall evaluation of professional learning community is decreasing. The evaluation of new teachers with 1-5 years' teaching experiences is significantly higher than that of older teachers with more than 10 years' teaching.

Third, the evaluation of teachers with master's and bachelor's degree is significantly higher than that of college degree teachers on the professional learning community. However, there is no significant difference between the master and undergraduate degrees. 
Fourth, teachers who majored in English and Education evaluated much higher on the professional learning community than those who graduated from other majors in other three dimensions except for the "shared value and vision".

Fifth, teachers who own TEM 4 and 8 certification evaluated significantly higher than who had non-qualified certification. However, there is no significant difference between the teachers with TEM 4 and TEM 8.

Sixth, teachers who work in high reputation and ordinary schools have higher evaluation on professional learning community than those who work in the average schools. However, there is no significant difference at the "shared and supportive leadership" dimension between different schools.

Seventh, teachers who come from in large-scale schools offer higher estimation on professional learning community than those middle and small school.

Table 5. ANOVA summary of professional learning community evaluation

\begin{tabular}{|c|c|c|c|c|c|c|c|c|c|c|}
\hline Variable & & $\mathrm{n}$ & $\mathrm{M}$ & $\mathrm{SD}$ & $\begin{array}{l}\text { Sum of } \\
\text { Sources }\end{array}$ & SS & $\mathrm{df}$ & MS & $\mathrm{F}$ & comparison \\
\hline \multirow{5}{*}{ Age } & $1.21-25$ & 10 & 3.9375 & .27670 & $\begin{array}{l}\text { Between } \\
\text { Groups }\end{array}$ & 16.088 & 4 & 4.022 & $7.121 * * *$ & $1>4$ \\
\hline & $2.26-30$ & 52 & 3.9721 & .98223 & $\begin{array}{l}\text { Within } \\
\text { Groups }\end{array}$ & 235.512 & 417 & .565 & & $2>3$ \\
\hline & $3.31-40$ & 221 & 3.6650 & .68556 & Total & 251.600 & 421 & & & $3>4$ \\
\hline & $4.41-50$ & 120 & 3.3594 & .73724 & & & & & & \\
\hline & $5.51-60$ & 19 & 3.6632 & .98715 & & & & & & \\
\hline \multirow{4}{*}{$\begin{array}{l}\text { Teaching } \\
\text { experiences }\end{array}$} & $1.1-5$ & 52 & 4.1870 & .91075 & $\begin{array}{l}\text { Between } \\
\text { Groups }\end{array}$ & 27.043 & 3 & 9.014 & $16.779 * * *$ & $1>2$ \\
\hline & $2.6-10$ & 53 & 3.8500 & .54123 & $\begin{array}{l}\text { Within } \\
\text { Groups }\end{array}$ & 224.558 & 418 & .537 & & $2>3$ \\
\hline & $3.10-15$ & 125 & 3.5972 & .55388 & Total & 251.600 & 421 & & & $3>4$ \\
\hline & 4.over 15 & 192 & 3.4229 & .82176 & & & & & & \\
\hline \multirow[t]{3}{*}{$\begin{array}{l}\text { Education } \\
\text { level }\end{array}$} & 1.master & 96 & 3.5378 & 1.03007 & $\begin{array}{l}\text { Between } \\
\text { Groups }\end{array}$ & 13.252 & 2 & 6.626 & $11.648 * * *$ & $1>3$ \\
\hline & 2.bachelor & 322 & 3.6689 & .65460 & $\begin{array}{l}\text { Within } \\
\text { Groups }\end{array}$ & 238.348 & 419 & .569 & & $2>3$ \\
\hline & $\begin{array}{l}\text { 3.junior } \\
\text { college }\end{array}$ & 4 & 1.9000 & .00000 & & 251.600 & 421 & & & \\
\hline \multirow[t]{3}{*}{ Discipline } & 1.English & 372 & 3.6492 & .77380 & $\begin{array}{l}\text { Between } \\
\text { Groups }\end{array}$ & 6.543 & 2 & 3.271 & 5.594* & $1>3$ \\
\hline & 2.Education & 40 & 3.5687 & .75699 & $\begin{array}{l}\text { Within } \\
\text { Groups }\end{array}$ & 245.057 & 419 & .585 & & $2>3$ \\
\hline & 3.others & 10 & 2.8375 & .25035 & & 251.600 & 421 & & & \\
\hline \multirow[t]{3}{*}{$\begin{array}{l}\text { English } \\
\text { Certification }\end{array}$} & 1.TEM 8 & 176 & 3.7841 & .79615 & $\begin{array}{l}\text { Between } \\
\text { Groups }\end{array}$ & 8.188 & 2 & 4.094 & $7.047^{*}$ & $1>2$ \\
\hline & 2.TEM4 & 159 & 3.5319 & .66630 & $\begin{array}{l}\text { Within } \\
\text { Groups }\end{array}$ & 243.412 & 419 & .581 & & \\
\hline & 3.no & 87 & 3.4603 & .85142 & & 251.600 & 421 & & & $1>3$ \\
\hline \multirow[t]{2}{*}{ School level } & $\begin{array}{l}\text { 1.high } \\
\text { reputation }\end{array}$ & 123 & 3.3697 & .87662 & $\begin{array}{l}\text { Between } \\
\text { Groups }\end{array}$ & 11.595 & 2 & 5.798 & $10.122^{*}$ & $2>1$ \\
\hline & 2.average & 82 & 3.7939 & .74672 & Within & 240.005 & 419 & .573 & & \\
\hline
\end{tabular}




\begin{tabular}{lllllllllll}
\hline & level & \multicolumn{7}{c}{ Groups } \\
\cline { 2 - 10 } & 3.ordinary & 217 & 3.7007 & .68410 & & 251.600 & 421 & $3>1$ \\
\hline School size & 1.large & 230 & 3.8502 & .60482 & $\begin{array}{l}\text { Between } \\
\text { Groups }\end{array}$ & 26.332 & 2 & 13.166 & $24.489^{*}$ & $1>2$ \\
& 2.medium & 159 & 3.3586 & .80427 & $\begin{array}{l}\text { Within } \\
\text { Groups }\end{array}$ & 225.268 & 419 & .538 & & \\
\cline { 2 - 10 } & 3. small & 33 & 3.3045 & 1.10815 & & 251.600 & 421 & & $1>3$ \\
\hline
\end{tabular}

Note: $* * * \mathrm{p}<.001, * \mathrm{p}<.05$, ns means for no significant difference. School Size: According to the regulations $<$ Standard for the Construction of School Buildings in Urban Primary and Secondary Schools $>$ of China, every academic class has 50 students in Chinese high schools. In this research, the criteria of school size were divided into three types. Small: $<18$ academic classes, 900 students; Medium:18-36 academic classes, 900-1800 students; Large: $>36$ academic classes, 1800 students. High reputation school means the resources from both national and province level. Average school obtain the resources from province level. Ordinary school get resources from regional level.

In sum, according to the Table 6 , teachers who were over 40 years old, graduated from teacher training schools, had at least 10 years teaching experiences, and worked in the high reputation schools have a lower evaluation to the professional learning communities. There is a tendency that the more the teachers participated in the professional learning communities, the lower evaluation they had. This can be seen from the old-generation teachers. Their professional learning communities' experiences must more than the younger generation. However, they marked a lower score for their feelings. It might connect their career development. After long-term working, they would be tired of the high pressure work load. They tend to have negative assessment of activities in school. In particular for the high reputation school, they obtain the best resources. Namely, they had to provide the best quality education to the students and the society. This criterion mainly relies on the passing rate of the national college entrance examination. Despite the fact that the rate of the examination is influenced by many potential elements, teachers might be attributed to the directly factor of unpleasant results.

On the other hand, teachers belong to the larger-scale school providing positive evaluation to the professional learning communities. One reason might link to the broad network. This network of the larger school provides the teachers with more opportunities and possibilities to solve its problems than the other schools. In despite of the lower assessment of formal degree teacher training, we agree that the gap between the pre-service education and current implementation in school system lead to the negative result. It also clarifies that in-service teaching training offers the space for the future teachers' professional development and school reform.

Table 6. Comprehensive summary of influencing factors of effective professional learning community evaluation

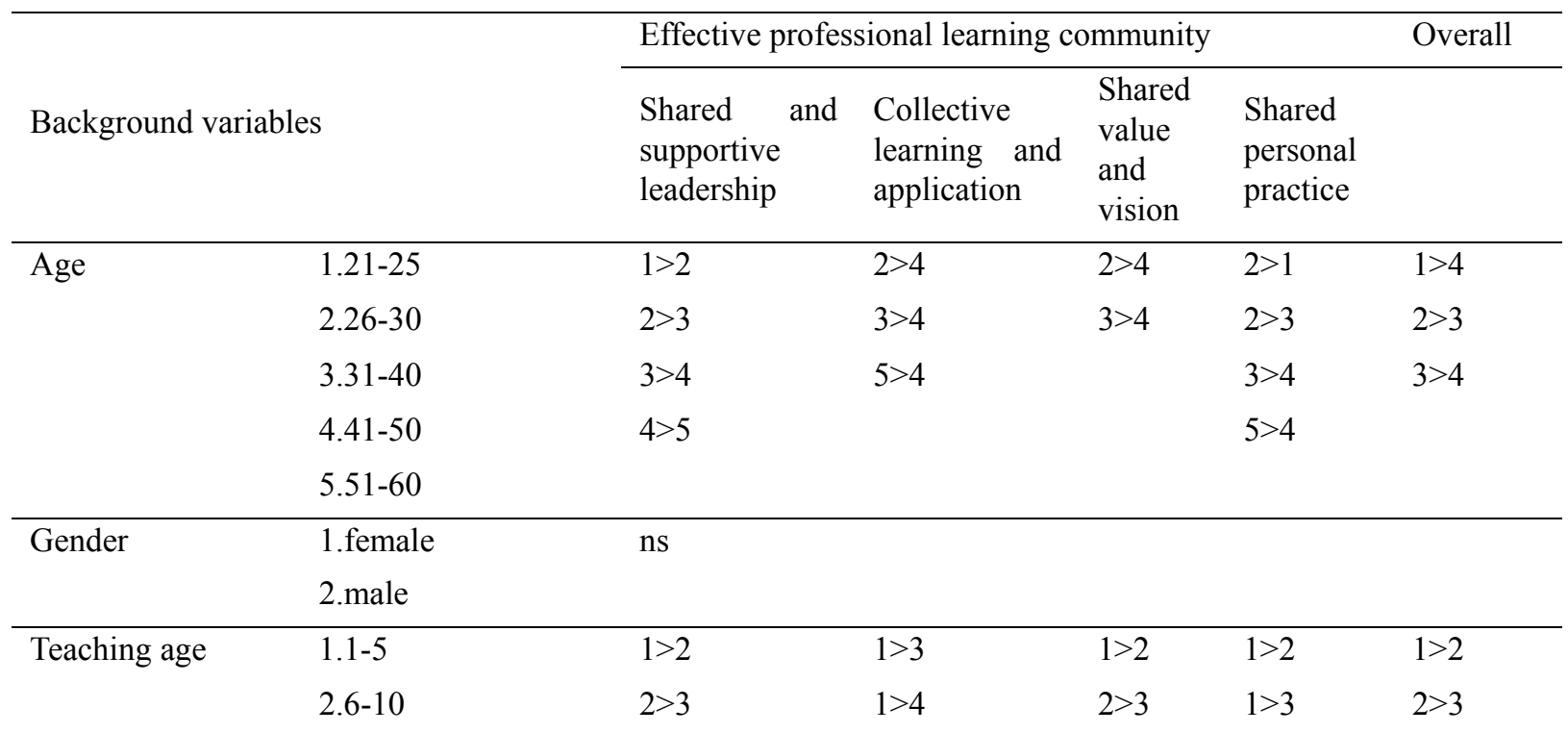




\begin{tabular}{|c|c|c|c|c|c|c|}
\hline & $3.10-15$ & $3>4$ & $2>3$ & $3>4$ & $1>4$ & $3>4$ \\
\hline & 4.over 15 & & $2>4$ & & & \\
\hline \multirow[t]{3}{*}{ Education level } & 1.master & $1>3$ & $1>3$ & $2>1$ & $1>3$ & $1>3$ \\
\hline & 2.bachelor & $2>3$ & $2>3$ & $2>3$ & $2>3$ & $2>3$ \\
\hline & 3.junior college & & & $1>3$ & & \\
\hline \multirow{2}{*}{$\begin{array}{l}\text { Graduated from } \\
\text { teacher training } \\
\text { university }\end{array}$} & 1.yes & $2>1$ & $2>1$ & ns & ns & $2>1$ \\
\hline & 2.no & & & & & \\
\hline \multirow[t]{3}{*}{ Disciplines } & 1.English & $1>3$ & $1>3$ & ns & $1>3$ & $1>3$ \\
\hline & 2.Education & $2>3$ & $2>3$ & & $2>3$ & $2>3$ \\
\hline & 3.others & & & & & \\
\hline \multirow[t]{3}{*}{ English certificate } & 1.TEM 8 & $1>2$ & $1>2$ & $1>2$ & $1>2$ & $1>2$ \\
\hline & 2.TEM4 & $1>3$ & $1>3$ & $1>3$ & $1>3$ & $1>3$ \\
\hline & 3.no & & & & & \\
\hline \multirow[t]{3}{*}{ School Level } & 1.high reputation & ns & $2>1$ & $2>1$ & $2>1$ & $2>1$ \\
\hline & 2.average level & & $3>1$ & $3>1$ & $3>1$ & $3>1$ \\
\hline & 3.ordinary & & & & & \\
\hline \multirow[t]{3}{*}{ School size } & 1.large & $1>2$ & $1>2$ & $1>2$ & $1>2$ & $1>2$ \\
\hline & 2.medium & $1>3$ & $1>3$ & $1>3$ & $1>3$ & $1>3$ \\
\hline & 3.small & & & & & \\
\hline \multirow{2}{*}{$\begin{array}{l}\text { Leader of the } \\
\text { community }\end{array}$} & 1.yes & ns & & & & \\
\hline & 2.no & & & & & \\
\hline
\end{tabular}

Note. ns means no significant difference.

\section{Discussions}

According to the overall analysis, this research shows that professional learning communities in the Chinese context shares the characteristics with western professional learning communities at some degree. The Chinse professional learning communities exhibit the nature of shared personal practice and collective learning and application. While English teachers' perceptions at shared and supportive leadership and shared value and vision experience a low estimation.

Firstly, because of the long-period top-down support of traditional schools-based professional learning communities from the government, schools and teachers have made a progress at the shared personal practice and the collective learning and application. Salleh and Clive's research also supports that the Ministry of Education policy in Singapore plays an important role to establish and implement the professional learning communities (Hairon \& Dimmock, 2012). In addition, researchers believe that after the long-term development, the professional learning community in Chinese high schools has formed a fixed professional development activity and teacher cooperation to improve classroom teaching, student learning and class management have become a part of daily teaching and learning. Therefore, teachers have a higher assessment of these two dimensions. The results of this study are consistent with the findings of Zhang and Pang for teacher professional learning community in Shanghai. In the unique Chinese context, these two dimensions appeared highly integrated with each other (Zhang \& Pang, 2016).

Secondly, more attention should be paid to the organisation construction. Such as the shared value and vision, shared and supportive leadership. The western style Professional learning communities is a bottom up unit rooting in the Anglo-American systems. It emphasizes the shared decision-making process and free discussion. Whereas, influenced by the Chinese hierarchical social system, the previous Soviet model professional learning communities is a top-down organization. This lead to the relatively lower scores of shared and supportive leaderships. In the Asian Confucian contextual, China is not the only case who experienced the lack of shared 
decision making. Professional learning communities in Korean's schools witnesses the same negative perceptions from the teachers at the decision making level (Seo \& Han, 2012).

Thirdly, teachers' work-load and pressure become a crucial element of their willingness in sustain participation in the professional learning communities. "The school where I work pays more attention to the students' study rather scores", is a single item whose score is lower than the average in the survey. In 2014, China's Ministry of Education began the biggest reform since the resumption of the college entrance examination in 1978. The English test changed from the final years' examination to two-times examination over the high school period. The higher score will be counted in the final scores of national college entrance examination. It means that students could got one more chance to have a better score. The influence of this change on senior high school English teachers remains to further study. The score-center evaluation method has an influence on teachers' behaviour and their task orders. Although high reputation schools enjoy the best quality resources, the challenges and pressures faced by them also are higher than other schools. The evaluation of the professional learning community from the teachers from this kind of school is significantly lower than that of the other teachers. In Wang's research on two key schools in Northeast China, based on the exam background, the teachers interviewed showed a dilemma in their overall development and exam scores (Wang, 2016).

\section{Conclusions}

With the development and implementation of professional learning communities in the world, its concept, dimensional and models become more various than before. It not only refers to the teacher and school, but also connects to the district. Slleegers et al suggests that professional learning communities should expand to the "dynamic relation between teachers' engagement in professional learning activities, the structural and cultural conditions that foster teachers' individual and collective learning (Sleegers, den Brok, Verbiest, Moolenaar, \& Daly, 2013)." Professional learning communities cannot be simply interpreted; it should be embedded to a multilevel model.

In this survey, there are significant differences in age and teaching experiences in the evaluation of teacher professional learning community. The teachers with younger age and shorter teaching experiences are significantly higher than the older with longer teaching period. After long period of teaching and working, older teachers supposed to acquire the most abundant experience of the professional learning community. While the reverse results mentioned before evidenced that the evaluation of teacher professional learning community has been influenced by the teachers' career development stage. According to Shao's survey, the novice teachers stays in the exploratory phrase and shows a higher enthusiasm and evaluation for their work. Mature teachers over 30 years old tend to have lower sense of achievement due to repetitive work (Shao, 2003). In this survey, more than half of the samples were from female teachers over 30 years old. The researchers hypothesized that the dual pressures of family and work may have a negative impact on the evaluation of English teachers in the professional learning community.

The evaluation of teachers, who graduated from English and pedagogical majors of teacher training universities, is significantly lower than those comprehensive universities or other majors. The current teacher education, as the academic center of Chinese educational research, has accommodated advanced international experience and theoretical guidance for future teachers in the pre-service training. While the reform speed of the organizational environment and characteristics in the Chinese primary and secondary schools is lagging behind universities. Therefore, after entering the post stage of career, the English teachers who have been professional trained tend to feel frustrated about the current professional learning community.

The Chinese government and the professional education organisations are collaborating with each other to promote the teachers' professional development and school improvement. The professional learning community, as an effective strategy for the in-service professional development, should play a more important role in schools. Owing to the hierarchy system and historical heritage, professional learning communities in Chinese schools already have had a good frame. The biggest challenge is how to improve the "shared and supportive leadership" of the professional learning community. The future research should focus on the faculty trust, the design of professional learning activities which can meet the different needs, mobilize the enthusiasm of the proficient teachers. A number of studies have confirmed that shared and supportive leadership plays an important role in the development of professional learning community (Stoll \& Louis, 2007). How to establish a fair, equal and democratic dialogue and cooperation among professional learning communities in the hierarchical cultural context still depends on further research and practice.

Some limitations exist in this study. The questionnaire design mainly based on the original questionnaire. The Anglo-American schools' cultural effect on the questionnaire design and items interpretation needs further 
comparison and modification. In the research of other scholars, collegial trust and faculty trust (Chen, Lee, Lin, \& Zhang, 2016), knowledge sharing (Chiu, Hsu, \& Wang, 2006; Hou, Sung, \& Chang, 2009) and other dimensions are found to be effective intermediate variables of "shared and supportive leadership" and "shared personal practice". They have a good role in promoting the development of an effective professional learning community. In the follow-up study, researches and practices of this dimension should be improved.

\section{References}

Bolam, R., McMahon, A., Stoll, L., Thomas, S., Wallace, M., Greenwood, A., ... Smith, M. (2005). Creating and sustaining effective professional learning communities. Bristol: University of Bristol y Departament of Education and Skills.

Chen, P., Lee, C.-D., Lin, H., \& Zhang, C.-X. (2016). Factors that develop effective professional learning communities in Taiwan. Asia Pacific Journal of Education, 36(2), 248-265. https://doi.org/10.1080/02188791.2016.1148853

Chiu, C.-M., Hsu, M.-H., \& Wang, E. T. (2006). Understanding knowledge sharing in virtual communities: An integration of social capital and social cognitive theories. Decision support systems, 42(3), 1872-1888. https://doi.org/10.1016/j.dss.2006.04.001

De Neve, D., \& Devos, G. (2017). How do professional learning communities aid and hamper professional learning of beginning teachers related to differentiated instruction? Teachers and Teaching, 23(3), 262-283. https://doi.org/10.1080/13540602.2016.1206524

DuFour, R., \& Eaker, R. (2005). Professional Learning Communities at Work TM: Best Practices for Enhancing Students Achievement. Solution Tree Press.

Gray, J., Kruse, S., \& Tarter, C. J. (2016). Enabling school structures, collegial trust and academic emphasis: Antecedents of professional learning communities. Educational Management Administration \& Leadership, 44(6), 875-891. https://doi.org/10.1177/1741143215574505

Hairon, S., \& Dimmock, C. (2012). Singapore schools and professional learning communities: Teacher professional development and school leadership in an Asian hierarchical system. Educational Review, 64(4), 405-424. https://doi.org/10.1080/00131911.2011.625111

Han, S., \& Yu, W. (2014). The review and reflection on the excellent teacher studio in China. Journal of Northeast Normal University (Philosophy and Social Sciences), 5, 196-200.

Hipp, K. K., \& Huffman, J. B. (2003). Professional Learning Communities: Assessment--Development--Effects.

Hord, S. M. (1998). Creating a Professional Learning Community: Cottonwood Creek School. Issues about change, 6(2), 2.

Hord, S. M. (2004). Learning together, leading together: Changing schools through professional learning communities. Teachers College Press.

Hou, H.-T., Sung, Y.-T., \& Chang, K.-E. (2009). Exploring the behavioral patterns of an online knowledge-sharing discussion activity among teachers with problem-solving strategy. Teaching and teacher education, 25(1), 101-108. https://doi.org/10.1016/j.tate.2008.07.006

Lee, I. (2015). Student Teachers' Changing Beliefs on a Pre-service Teacher Education Course in Hong Kong Experiences of Second Language Teacher Education (pp. 15-41): Springer. https://doi.org/10.1057/9781137316257_2

Lee, J. C.-K., Zhang, Z., \& Yin, H. (2011). A multilevel analysis of the impact of a professional learning community, faculty trust in colleagues and collective efficacy on teacher commitment to students. Teaching and teacher education, 27(5), 820-830. https://doi.org/10.1016/j.tate.2011.01.006

Olivier, D. F., Hipp, K. K., \& Huffman, J. (2010). Assessing and analyzing schools as professional learning communities. Demystifying professional learning communities: School leadership at its best, 29-41.

Seo, K., \& Han, Y.-K. (2012). The vision and the reality of professional learning communities in Korean schools. KEDI Journal of Educational Policy, 9(2).

Shan, Z. (2014). Towardsthe Reform of Teaching and Research Groupof Professional Learning Communities with Chinese Characteristics. Educational researcher, 35(10), 86-90.

Sleegers, P., den Brok, P., Verbiest, E., Moolenaar, N. M., \& Daly, A. J. (2013). Toward conceptual clarity: A multidimensional, multilevel model of professional learning communities in Dutch elementary schools. The 
Elementary School Journal, 114(1), 118-137. https://doi.org/10.1086/671063

Stoll, L., Bolam, R., McMahon, A., Wallace, M., \& Thomas, S. (2006). Professional learning communities: A review of the literature. Journal of educational change, 7(4), 221-258. https://doi.org/10.1007/s10833-006-0001-8

Stoll, L., \& Louis, K. S. (2007). Professional learning communities: Divergence, depth and dilemmas. McGraw-Hill Education (UK).

Vescio, V., Ross, D., \& Adams, A. (2008). A review of research on the impact of professional learning communities on teaching practice and student learning. Teaching and teacher education, 24(1), 80-91. https://doi.org/10.1016/j.tate.2007.01.004

Wang, T. (2016). School leadership and professional learning community: Case study of two senior high schools in Northeast China. Asia Pacific Journal of Education, 36(2), 202-216. https://doi.org/10.1080/02188791.2016.1148849

Zhang, J., \& Pang, N. S.-K. (2016). Exploring the characteristics of professional learning communities in China: A mixed-method study. The Asia-Pacific Education Researcher, 25(1), 11-21. https://doi.org/10.1007/s40299-015-0228-3

Zhang, J., \& Sun-Keung Pang, N. (2016). Investigating the development of professional learning communities: compare schools in Shanghai and Southwest China. Asia Pacific Journal of Education, 36(2), 217-230. https://doi.org/10.1080/02188791.2016.1148851

\section{Copyrights}

Copyright for this article is retained by the author(s), with first publication rights granted to the journal.

This is an open-access article distributed under the terms and conditions of the Creative Commons Attribution license (http://creativecommons.org/licenses/by/4.0/). 